\title{
India: a Case of Fragile Wireless Service and Technology Adoption?
}

\author{
L-F Pau and J. Motiwalla
}

\begin{tabular}{|l|l|}
\hline \multicolumn{2}{|l|}{ ERIM REPORT SERIES RESEARCH IN MANAGEMENT } \\
\hline ERIM Report Series reference number & ERS-2007-011-LIS \\
\hline Publication & February 2007 \\
\hline Number of pages & 30 \\
\hline Persistent paper URL & \\
\hline Email address corresponding author & Ipau@rsm.nl \\
\hline Address & Erasmus Research Institute of Management (ERIM) \\
& RSM Erasmus University / Erasmus School of Economics \\
& Erasmus Universiteit Rotterdam \\
& P.O.Box 1738 \\
& 3000 DR Rotterdam, The Netherlands \\
& Phone: + 31104081182 \\
& Fax: $\quad+31104089640$ \\
& Email: info@erim.eur.nl \\
& Internet: www.erim.eur.nl \\
\hline
\end{tabular}

Bibliographic data and classifications of all the ERIM reports are also available on the ERIM website: www.erim.eur.nl 


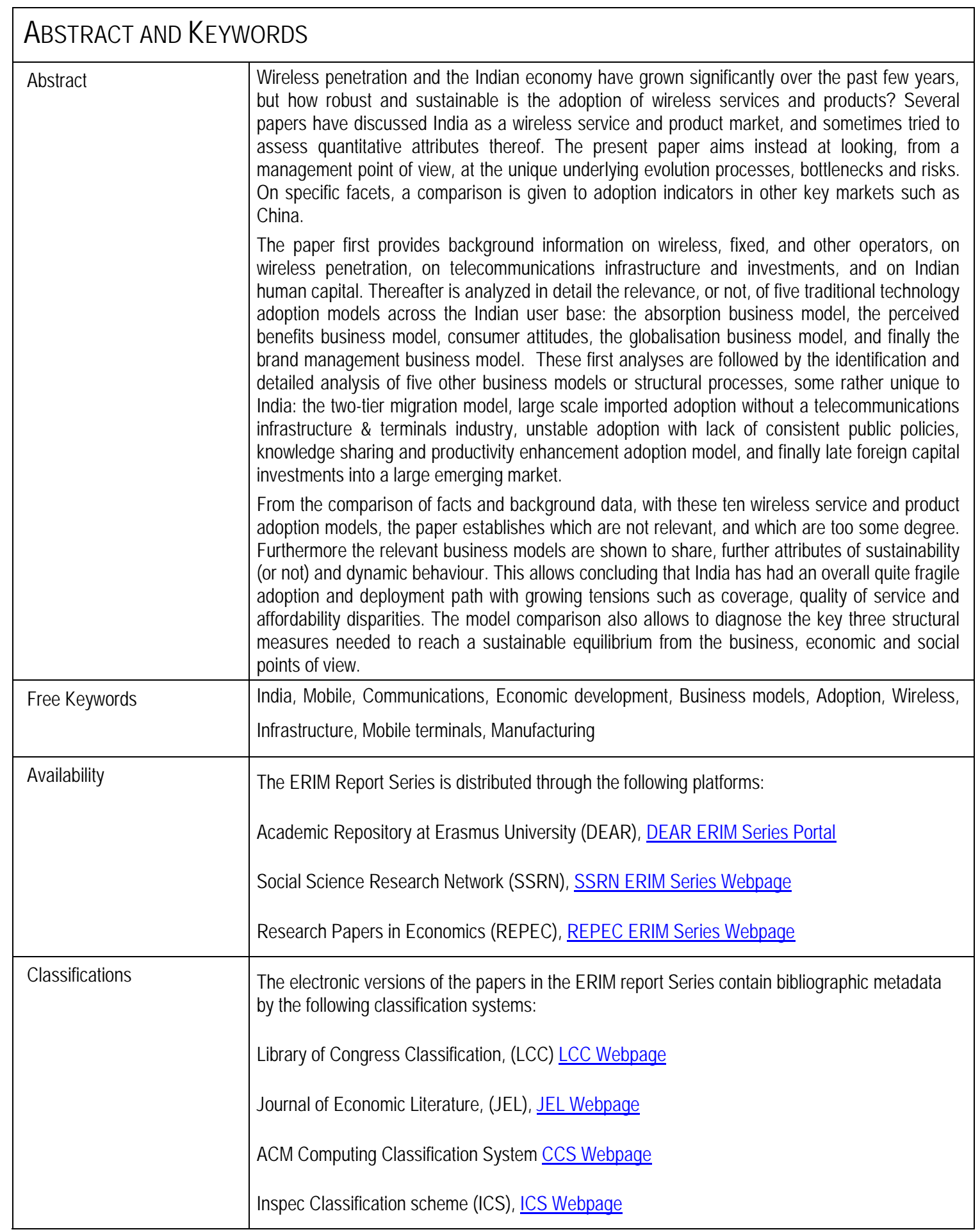




\title{
India: a case of fragile wireless service and technology adoption?
}

L-F Pau, Professor Mobile business, RSM Rotterdam school of management, and J. Motiwalla , Green Dot Capital Singapore ; email :lpau@rsm.nl

\begin{abstract}
:
Wireless penetration and the Indian economy have grown significantly over the past few years, but how robust and sustainable is the adoption of wireless services and products? Several papers have discussed India as a wireless service and product market, and sometimes tried to assess quantitative attributes thereof. The present paper aims instead at looking, from a management point of view, at the unique underlying evolution processes, bottlenecks and risks. On specific facets, a comparison is given to adoption indicators in other key markets such as China.
\end{abstract}

For example, just to illustrate highlights of these unique attributes , it is indeed surprising that such a major economy with its very large population has not yet achieved the wireless service usage and mobile terminal penetration ratios of neither an early European adopter ,nor of a recent large scale adopter like China or Russia . India has also been characterised by a surprising regulatory development process quite different from many other contexts, both in terms of its both centralised and regional structure, of very low tariffs providing almost no ROI to investors in a stable situation, and of absence of neutrality across communications technologies. At the same time, a very large fraction of the population has not , for affordability and regional coverage reasons, been able to get the access opportunities of more developed regions, leading to a distribution unbalance which is also a significant opportunity .Also, the wireless service and product adoption pattern in India , specific 
to communication services, has so far been in rather sharp contrast with the widely known software and outsourcing services industry evolutions in that country .

Therefore it is important to compare the most relevant known wireless service and product adoption theories, to establish from facts whether they apply in the Indian context, and, if not, suggest new or mixed theories able to explain all such facts and cast some light into its likely future structural evolution. It is of high relevance in management to validate if indeed established models apply or not in a significant case like India, just as it is also of high relevance for the main stakeholders to identify methodology able to support their analyses.

The paper first provides background information on wireless, fixed, and other operators, on wireless penetration, on telecommunications infrastructure and investments, and on Indian human capital. Thereafter is analyzed in detail the relevance, or not, of five traditional technology adoption models across the Indian user base: the absorption business model, the perceived benefits business model, consumer attitudes, the globalisation business model, and finally the brand management business model. These first analyses are followed by the identification and detailed analysis of five other business models or structural processes, some rather unique to India: the two-tier migration model, large scale imported adoption without a telecommunications infrastructure \& terminals industry, unstable adoption with lack of consistent public policies, knowledge sharing and productivity enhancement adoption model, and finally late foreign capital investments into a large emerging market.

From the comparison of facts and background data , with these ten wireless service and product adoption models, the paper establishes which are not relevant, and which are too some degree . Furthermore the relevant business models are shown to share, further attributes of sustainability (or not) and dynamic behaviour. This allows concluding that India has had an overall quite fragile adoption and deployment path with growing tensions such as coverage, quality of service and affordability disparities. The model comparison also allows to diagnose the key three structural measures needed to reach a sustainable equilibrium from the business, economic and social points of view. 


\section{Keywords}

India, Mobile, Communications, Economic development, Business models, Adoption, Wireless, Infrastructure, Mobile terminals, Manufacturing

\section{NOTE}

The reader familiar with the details of the Indian situation, or not wishing to have background details, can skip the BackgroundInformation Section 0. and start with the Section 1 about the Goal of the paper.

\section{O. BACKGROUND INFORMATION}

This Section summarizes background data on wireless penetration and operators, financials, teledensity and demographic structure.

Table 1: MOBILE OPERATOR MARKET SHARES (Source: Telecom regulatory authority of India, June 2005); Total: 57, 37 M wireless users; Average wireless penetration (2005) : < 6 \%; Approx growth: + 1, 6 M users/month

\begin{tabular}{|l|l|l|}
\hline MAIN WIRELESS OPERATORS & $\begin{array}{l}\text { Capitalization on } \\
08 \text { May 2006 }\end{array}$ & Market shares \\
\hline $\begin{array}{l}\text { Bharti Airtel (Singapore Telecommunications } \\
\text { Ltd. owns a 31\% stake) }\end{array}$ & $\begin{array}{l}17,4 \text { BUSD } \\
\text { Reliance }\end{array}$ & $\begin{array}{l}\text { Part of } \\
\text { conglomerate }\end{array}$ \\
\hline BSNL (state owned) & $\begin{array}{l}100 \% \\
\text { Government } \\
\text { owned }\end{array}$ & $18,6 \%$ \\
\hline $\begin{array}{l}\text { Hutchison Essar (62 \%-owned by Hutchison } \\
\text { Telecommunications International Ltd. of } \\
\text { Hong Kong) }\end{array}$ & 8,9 BUSD & $14,7 \%$ \\
\hline & & $9,7 \%$ \\
\hline \begin{tabular}{l} 
IDEA \\
\hline
\end{tabular} & & \\
\hline
\end{tabular}




\begin{tabular}{|l|l|l|}
\hline Others & $15,3 \%$ \\
\hline
\end{tabular}

\section{Wireless operators}

State owned fixed operator Bharat Sanchar Nigam Ltd BSNL is also the third largest mobile operator). BSNL which is the operator with widest coverage reaches 7000 towns and villages, far from the 650000 villages in India. More than $90 \%$ of the Indian subscribers have signed up since 2003. The other main fixed operator is Mahanagar Telephone Nigam (MTNL), which had on May 08, 2006 a market capitalization of 3.0 BUSD although it is partly $56 \%$ state owned, and which also provides wireless service.

The two state owned integrated operators BSNL and MTNL were considering a merger at the end of 2006. While BSNL operates in all of the country's circles except Mumbai and Delhi, MTNL was set up primarily to provide fixed, mobile, and broadband access to the country's two largest cities. The merger of these two telcos will create the largest telecom company in the country with It will result in the creation of a robust entity which the lastmile advantage across the country, a stronger balance sheet, economies of scale, will control over $90 \%$ of the fixed-line market and around $18 \%$ of the wireless market with a total subscriber base of over $45 \mathrm{~m}$ (as mid 2005).

As a result of the National Telecommunications policy of 1999, were licensed eight cellular wireless operators in four metropolitan areas, cellular operators in 18 state areas, six fixed communications operators in six state areas, and two paging operators in 27 cities and 18 state areas (Telecommunications regulatory authority of India (TRAI), 1999). In case of Very Small Aperture Terminal (VSAT) satellite communications , 14 licenses were awarded out of which only nine were made operational (TRAI,1999). The initial results in terms of wireless service adoption were not satisfactory as only 1million subscribers had subscribed to the cellular services, and operators suffered as these numbers fell well short of projected targets (TRAI, 1999). As of 2006, there are still about 12 wireless operators, of which the main five ones are mentioned din Table 1, and there are five private fixed operators (in addition to state owned BSNL and MTNL).

\section{Wireless penetration}


When the National Telecommunications Policy of 1994 was tabled, teledensity in India was 0.8 per a hundred people in contrast with the world average of 10 (TRAI , 1994); it was also lower as compared to China, Pakistan, and Malaysia .

Since then the growth has been significant with a teledensity of 7 reached in March 2004 (although the rural teledensity was only 1, 7 reaching 522000 villages out of a total of 620 000) (TRAI, 2005). According to (TRAI's ,April $\left.10^{\text {th }}, 2006\right)$ press release, gross telecom subscribers reached around 140 million telephone users, of which fixed subscribers are 49.5million and mobile subscribers, 90 million .As of December 2005. teledensity reached 11.43\%, of which mobile (GSM + CDMA) services accounted for $6.95 \%$ and fixed services, including WLL accounted for the rest (TRAI, April 2006) . But these figures are imbalanced because the urban teledensity is more than $31 \%$ but only 2\% in the rural areas (Light reading). As of Dec 2005, the market share of mobile subscribers in metro areas is about $25.98 \%$, in Circles A, 35.05\%, in Circles B, 32.29\%, and in Circles C, 6.68\% (TRAI, April 2006), In the rural areas, more than 14.18 million phones had been provided, but this pales in comparison to the 35 million phones in urban areas (TRAI, April 2006).

Telecom Regulatory Authority of India (TRAI), the Department of Telecommunications (DoT) and the Wireless Planning Commission (WPC) have recommended in 2005 actions to take in order to ensure that India achieves a goal of $250 \mathrm{~m}$ telephone lines by the end of 2007 , of which $200 \mathrm{~m}$ are expected to be mobile or fixed-wireless, and representing a growth of $150 \mathrm{M}$ subscribers compared to 2004. This would represent by the end of 2007 a teledensity of $22 \%$.To achieve this aggressive growth target, mobile operators would need to add, at the very least, $4 \mathrm{~m}$ subscribers per month for a period of 36 months since 2004 .

\section{Telecommunications infrastructure and investments}

According to the Economic Survey of India 2005-2006, the telecommunications infrastructure deficit continues to haunt India (Government of India, 2005). It has been estimated that India has the potential to absorb US\$150 Billion of foreign direct investment (FDI) over 2005-2010 in the infrastructure sector alone (Government of India, 2005). As far as foreign ownership in the telecommunications sector is concerned the ceiling has been raised from $49 \%$ from 1999 to 2005 , to $74 \%$ in certain areas such as basic, cellular, unified access services, national/international long distances, VSAT, PMRTS , Internet service providers with gateways (Government of India , 2005) . A total of 
Rs. 41,551 core FDI was approved for the telecom sector through Sep 2005 ; Hutchison, SingTel, AT\&T and Distacom are the major investors. Furthermore, since the first five-year national plan (1951), the government has allocated 3.5\% of national outlays to the communications industry on average (Indiastat). Since Aug 1991 to Sep 2005, the telecommunications sector has attracted a cumulative inflow of Rs. 12,076 crore (US $\$ 2,863$ Million), which amounts to $9.60 \%$ of the total FDI inflows attracted by India (Government of India ,2005).

\section{Human capital}

United Nations Development Program (UNDP’s) global Human Development Report (HDR) for 2005 ranks India at 127 out of 177 countries in terms of a composite Human Development Index (HDI) for 2003, while China is ranked 85 (UNDP) but India has stagnated. According to the Census 2001 results, India registered a literacy rate of 64.84\% for a country with a population of more than a billion; this is not a bad indicator but lags behind China's literacy rate of 95.1\% (Census of India). Alphabetisation represents 30-40 \% of adults, much higher than China (UNESCO Statistical directory, 2001) .In terms of Gender Development Index (GDI), India ranks $98^{\text {th }}$, behind $64^{\text {th }}$ ranked China (Government of India,2005) (UNDP) . This shows there are higher gender disparities in India than in China. For example, looking at the most important states (Andhra Pradesh, Uttar Pradesh, Delhi, West Bengal, Madhya Pradesh, Karnataka, Kerala, Tamil Nadu, Maharashtra, and Rajasthan), the state with the highest literacy rate is Kerala (90.9\%) with a population of 31 million (according to Census 2001), whereas Uttar Pradesh with a population of 166million has a literacy rate of 56.3\% (according to Census 2001), well below the all India literacy rate of $64.84 \%$ (Census of India) . Furthermore, only $9 \%$ to $13 \%$ of the total expenditure of the country has been devoted toward education (Indiastat). Specifically, it has increased from 9.7\% in 2003-04 to 10.1\% in 2005-06 (budget estimates) (Government of India, 2005). This can be attributed to the fact that the social sector falls under the state's portfolio and not under the central government.

India's key advantage is in the availability of skilled, intelligent, cost-effective manpower, and large English speaking community. For example, consider the Indian software industry. Some of the key statistics of India's ICT manpower are defined as follows (NASSCOM): The IT industry employs more than 800k professionals in companies related to software exports, software-domestic, software-captive in user organizations. The overall median age of the software professional is about 27.5 years. $81 \%$ of all the software 
professionals have graduate or higher degrees. But one can find them only in areas where opportunities exist, infrastructure is well-developed, business opportunities are abundant and much regionalized, i.e., exist in cities such as Mumbai, Bangalore, Delhi, Noida, Calcutta, Pune. According to results of the $60^{\text {th }}$ round of NSSO survey (Jan-Jun 2004), about $72 \%$ of the households belonged to rural India and accounted for nearly $75 \%$ of total population. In the rural areas, about $66 \%$ of usually employed males and $84 \%$ of usually employed females are engaged in the agricultural sector (Government of India, 2005). Unemployment rates went up between 1993-94 and 2004. It can be safely said that

keeping the political scenario aside, India has to invest more in the development of the educational system and creation of business opportunities.

\section{GOAL OF THE PAPER}

Several papers have discussed India from the point of view of a wireless service and product market, and sometimes tried to assess quantitative attributes thereof. This is not the intent of the present paper which aims instead at looking from a management point of view at the unique underlying evolution processes, bottlenecks and risks.

For example, just to illustrate highlights of these unique attributes, it is indeed surprising that such a major economy with its very large population has not yet achieved the wireless service usage and mobile terminal penetration ratios of neither an early European adopter ,nor of a recent large scale adopter like China or Russia (Sangwan \& Pau, 2005) .

India has also been characterised by a surprising regulatory development process quite different from many other contexts, both in terms of its both centralised and regional structure, of absence of technology neutrality. At the same time, a very large fraction of the population has not for affordability and regional coverage reasons been able to get the access opportunities of more developed regions, leading to a distribution unbalance which is also a significant opportunity. Recently foreign and domestic investors have grown a proportionately large appetite for early phase wireless operators in India. Last but not least, the wireless service and product adoption pattern in India, specific to communication services, has so far been in rather sharp contrast with the widely known software and outsourcing services industry evolutions. 
Therefore it is important to compare the most relevant known wireless service and product adoption theories, to establish from facts whether they apply in the Indian context, and, if not, suggest a new or mixed theory able to explain all such facts and cast some light into its likely future structural evolution. It is of high relevance in management to validate if indeed established models apply or not in a significant case like India, just as it is also of high relevance for the main stakeholders to identify methodology able to support their analyses.

Finally the applicability of such a new or mixed theory to other technology sectors of the Indian economy must be assessed.

\section{RELEVANT TRADITIONAL MODELS}

This Section reviews relevant business models from the litterature in terms of their relevance for the Indian wireless service and product adoption.

\section{1) ABSORPTION BUSINESS MODEL}

Conceptually, wireless successes hinge on how well users and businesses can absorb pertinent information and apply the knowledge they have gained towards meeting social needs, and developing products and services. The success of innovating products and services requires critical investments in the accumulation of knowledge (Kanter, 1983), (Rogers, 1983), (Cohe and Levinthal, 1990) (Stock, Greiss and Fisher, 2001).

A community's absorptive capacity, i.e. the ability to recognize and assimilate information and apply its cumulative knowledge towards a social or profit gain, defines this ability. (Zahra and George,2002,p.186) define absorptive capacity as a "set of organizational outlines and processes by which firms or individuals acquire, assimilate , transform and exploit knowledge to produce a dynamic organisational capability" .As more knowledge is accumulated the organisation's absorptive capacity grows as its ability to recognize and assimilate information expands . 
To explain the growth of wireless services and products in India from this theory, one hypothesis is that India has had, thanks to education and social structure, a greater absorptive capacity than some other large emerging economies, and that, as a result , it will be more innovative ,but will also more accurately meet and satisfy customer needs . However sofar the absorptive capacity has been very small for products, industrial development, and value added services and in the rural areas of the country, which to some extent invalidates this hypothesis .Also it is unclear if there has been any impact on the organizational absorptive capacity.

\section{2) PERCEIVED BENEFITS BUSINESS MODEL}

In this typical model used in the communications industry, perceived benefits refer to the anticipated advantages that an innovation can provide to a community or organization ,and impact IT and communication services adoption .As communities are motivated by the perceived benefits from the adoption of an innovation, they realize the need to use the technology fully and integrate it with existing applications .Once the organization is convinced of the relative advantages, it tends to allocate the managerial , financial and technological resources necessary for the adoption .The availability of the necessary resources including the technical infrastructure also facilitates higher technical knowledge , which in turn increases the use of assimilation .

To explain the growth of wireless services and products in India from this theory, one hypothesis would be that the public and business interests have identified the perceived benefits and taken the needed action .However, the late and slightly perturbed regulatory framework for wireless service deployment and investments, seem to invalidate this hypothesis in the early phases of wireless service deployment up to approximately 2003.

\section{3) CONSUMER ATTITUDES}

In this theory linked to consumer behavior, its is the benefits as perceived by potential end users on the basis of their information, which drive the latent demand until other stakeholders create the knowledge, regulatory and investment frameworks to satisfy it . This is especially important for value added services; as shown by (Liao, 2005) from survey data (including for India) the consumer perceived usefulness, ease of use, behavioral control and reliability all positively influencee consumer's intentions to use SMS. To explain the growth of wireless 
services and products in India from this theory ,one hypothesis is that the information access in India about end user benefits from wireless voice and SMS has been strong enough to fuel the implementation through India's democratic processes .But the same survey has also shown that subjective social norm does not influence the consumers intention to use SMS and that the behaviour of other people has little impact in the case of mobile SMS ;even if SMS does not represent all wireless basic services it has globally been so far a strong adoption force mostly amongst youth .Furthermore Indian industry does not yet have a tradition for responding to consumer demands for public services , transport and housing . This web of facts seems to invalidate this hypothesis in the Indian case.

\section{4) GLOBALISATION BUSINESS MODEL}

India is one of the leading emerging markets in the world today. Developed economies view India as a major destination for expansion, offshore research and development. Thus the global and historic business model just reflects domestic as well as foreign will to extend the capabilities and reach of wireless services and products in India like everywhere else under competitive rules set by WTO. The end result should be the minimum average global connectivity of any economic actor and user in India. The issue of finding the relationship between communications service adoption and economic growth has been studied by researchers in different environments. (Kala and Vardharajan ,2003) study the relationship between telecommunications and the economic growth for developing nations.; that study finds that traditional economic factors explain demand for main phone lines, not for the cellular phone services. The total impact of telecom penetration on the total output is however significantly lower for developing countries than that reported for OECD countries. (Hudson ,2004)'s study gives a broad overview of how to get to broadband from lessons learned from the wireless explosion and expansion of telecommunications networks. (Hong, 2004) empirically establishes the relationship between GDP, employment, illiteracy rate, and population density as the relevant factors that influence telecom development in twelve provinces of China.

Table 2: Comparative Analysis of Indian and Chinese Telecom Industry Source: TRAI Report No. 1/2005, available at http://www.trai.gov.in 


\begin{tabular}{|l|l|l|}
\hline & India & China \\
\hline Fixed Lines (million) & 49.75 (as of Mar 06) & 325.40 (as of Mar 05) \\
\hline Cellular Lines (million) & 90 (as of Mar 06) & 349.10 (as of Mar 05) \\
\hline Total Revenue (billion) & $\$ 17.78$ (est. Mar 05) & $\$ 65.30$ (as of Dec 04) \\
\hline ARPU & & \\
\hline Basic Services & $\$ 15$ (as of Mar 05) & $\$ 9.17$ (as of Dec 04) \\
\hline Mobile (GSM and CDMA) & $\$ 9.04$ (as of Mar 05) & $\$ 9.69$ (as of Dec 04) \\
\hline Competitive Position & & \\
\hline Basic Services & 67 (as of Dec 04) & .58 (as of Dec 04) \\
\hline Mobile Services & 16 (as of Dec 04) & .40 (as of Dec 04) \\
\hline OpEx per Subscriber & & \\
\hline Basic Service & $\$ 5.92$ & $\$ 4.30$ \\
\hline Mobile Service & $\$ 4.18$ & $\$ 2.41$ \\
\hline
\end{tabular}

Table 2 illustrates the key differences in variables when comparing the Indian and Chinese telecommunications industry:

Fixed and Mobile Connections: It is clear that the Chinese market has seen a higher growth rate when compared to the Indian market. In the last five to six years, India's telecom growth rate has been more than that of China. This was largely possible due to policy changes, namely, introduction of new telecommunications policy, competitions, and growth in the economy due to which the purchasing power of people has increased. India has become the fifth largest telephone network in the world after China, USA, Japan, and Germany. According to Mr. Dayanidhi Maran, Minister of Communications and IT, India, it is expected that at the end of 2007 there will be 250million telephone lines (fixed and mobile) in India, with a teledensity of $22 \%$.

Total Revenue and OpEx/Subscribers: Total revenues of Indian service providers are low when compared to Chinese telecom players. Operational expenditures are higher for Indian operators when compared with their Chinese counterparts. This is expected because currently operators in India are looking to build networks, expand to new geographical areas, costs associated with customer acquisition are higher, and so is the marketing cost.

ARPU: ARPU's are comparable in the mobile service segment but in case of fixed services, India is much higher than China (Sangwan \& Pau, 2005). 
To explain the growth of wireless services and products in India from this theory, one hypothesis is that government and regulatory bodies have helped in improving the communications infrastructure everywhere and has offered incentives and/or transparent rules for competition to unfold. The National Telecommunications Policy, 1999 (NTP '99) was the first major initiative by the government in reviving the telecom industry in India. NTP '99 was targeted toward improving the nation's teledensity and network infrastructure. These policies and licenses have helped India to engage competition in the information highway market and help, to some extent, in increasing the penetration. However, penetration is still far behind major developing economies in the world. In last 50 years, total teledensity growth rate is $1.92 \%$ (TRAI : Telecom Regulatory authority of India ,2005), which is very low even if has soared from $0.5 \%$ in 1991 to $12.73 \%$ in 2006 , but so has the population of the county (1.02bn, according to (Census 2001)) . In the case of India, (Rai and Lal ,2000) identify that growth in information society depends on socio-economic development, education, telecommunication, and media as the factors contributing to the growth of the gross domestic product of a country. Furthermore, the article discusses the position of India in different sectors that are an integral part of the information revolution. (Gupta ,2004)'s work reveals that government efforts in resolving the regulatory and legal uncertainties are not always enabling the government to achieve public interest goals. (Press et. al. ,2003) compare China and India on the six dimension framework: pervasiveness, geographic dispersion, organization infrastructure, connectivity infrastructure, sectoral absorption, and sophistication of use; their study finds that China continues to have a substantial lead over India in Internet diffusion. More generally, (Sangmoon, 2005)'s research identifies that market and technological factors have a great impact on the explosive diffusion speed, while government and social factors contribute less to the diffusion process. All these studies for wireless as well as other communication services adoption seem to invalidate to a large extent the stated hypothesis.

\section{5) BRAND MANAGEMENT BUSINESS MODEL}

Brand management in India has been very strong in the mobile area. Operators built brand equity, and the choice of symbols and media whereby they have added or subtracted from customers' perceived value of the brand was done; as the choice was rather narrow, the task was eased.

To explain the growth of wireless services and products in India from this theory, one hypothesis is that efficient brand and relatively easy brand management contributed 
significantly to this growth. Although studies on brand impact in India in the communications area are very few, they point at a high impact not matched however outside affluent layers in the society by any wireless service adoption. In other words, this hypothesis can maybe explain in parts the high adoption rate in the more affluent groups in the society, but is overridden for the rest of the population by affordability constraints.

\section{IDENTIFIED UNIQUE MODELS}

Amongst those unique service and product adoption structural drivers which have been identified, the following seem to have the highest explanatory contribution to the justification of the past and current situation :

India can appear as a case in two-tier migration ,not towards an under-developed deployment coexisting with a normal adoption (like in many countries) ,but towards a situation involving growth in both wireless services (mostly in coastal cities ) and in converged fixed +fixed wireless services (mostly in the countryside) .

India can appear as a case in limited domestic telecommunications infrastructure and terminals domestic industries, largely outweighed by strong and global presence in information processing service support (software , outsourcing, etc ) ; this is e.g. in sharp contract to Japan , China and Taiwan India can appear as a wireless service and product evolution with growth but also strong drivers towards a downturn , with minimal support and a lot of constraints by governments whose influence has been rather fragmented in time and scope .India can appear as a case in which wireless services (cellular, fixed wireless ,etc..) appear to be a knowledge sharing and productivity tool ,and not as a manufacturing employment contributor. India can appear as a case of a market where, despite a rather favourable merger and acquisition framework , foreign networks operators have been more followers than initiators

\section{1) TWO TIER MIGRATION MODEL}

In most significant wireless service and product adoption markets, like China, Russia, Mexico, Egypt and others, the technology selection of wireless was seen as a way to leapfrog additional investments and slow provisioning in fixed or fixed broadband telephony. Indian regulators and policy makers are planning to up the ante by implementing policies that will lead to an additional 150m telephone lines being installed by the end of 2007 
; this will lead to an approximate fixed-line subscriber base of $50 \mathrm{~m}$, with the remaining $200 \mathrm{~m}$ being either fixed-wireless or mobile subscribers .The country's Communications Minister announced that the government is targeting 250m telephony subscribers by 2007, seeking to increase teledensity to 22 percent largely with higher fixed line penetration.

Such policies, and facts below, confirm that in India the migration to wireless services (cellular and fixed wireless) co-exists with continued growth in the fixed segment, and in the future with fixed broadband.

An unusually high percentage of the country's population, about 72 percent, resides in rural areas, compared to 58 percent in Indonesia and 60 percent in China. More importantly, India's rural GDP per capita is much lower at US\$352 compared to US\$765 in China. Since a significant portion of growth would likely have to come from the country's rural areas, for India to achieve its vision of 200 million mobile subscriptions, return on investment (ROI) becomes a major issue. Coverage expansion in rural areas, where the terrain is rough, has proven in many instances to be an expensive proposition. Moreover, the inability of the rural user to pay as much for services as the urban poses another equally serious problem. There are over 550,000 villages with less than 5,000 people residing in them. None of these have any mobile coverage as of today. Moreover, only 2,500 of India's roughly 5,200 towns are covered by mobile networks. With population coverage of only 22 percent, the issue of increasing teledensity in the country is not only capacity related, but also a problem of coverage, requiring a great deal of investment from the operators. Although equipment vendors have begun developing unique products, such as site-less and shelter-less radio base stations, which help operators reduce the total cost of network ownership, we still believe that the capital investment required to blanket a significant portion of the country (above 50\%) is not within the means of any single operator. As such, a significant shift in policy, such as telecom authorities in the country allowing network sharing in rural areas, is required to increase population coverage and eventually teledensity, over such a short period of time.

But noteworthy enough, there is still strong growth in fixed subscriptions, with an aggregate increase of $117 \%$ between 1995 and 2000. Fixed-line telephony which had given way to mobile phones is now back in focus. Most of the integrated players including Reliance, Bharti Televentures and BSNL are betting big on wireline phones and are rolling-out optical fiber cables with copper in the last mile across the country. While Reliance 
Infocomm (Reliance) said that fixed-lines would become the company's mainstay in the long run, Bharti Televentures (Bharti) has spread its fixed-line network to 14 circles from five. State-owned BSNL is set to issue a major tender for installing IP-based network across all its major exchanges around the country. Even MTNL, which operates in Delhi and Mumbai, is introducing new features, such as picture messaging and ring tones on its fixed-line terminals to make it more attractive to consumers who have opted for mobile service.

Furthermore mobile, fixed or fixed wireless deployment in rural India has a user multiplier to it, in that each installed line can serve many more thanks to the "village operator " effect (so called Village Panchayat Telephones, or sometimes walking mobile operators ). They often charge twice the operators rates to people using their mobile terminals; out of the profit they repay loans and consume. The average village phone bill is about twice the average urban mobile ARPU .The western operators which have invested in local operators running such village services (such as Telenor's 51 \% stake in Grameen Telecom in Bangladesh) have been quite satisfied. TRAI, WorldTel, Rutel (Canada) has long been pushing for subsidies to rural telecommunications; most active operator following this seems to be BNSL. Joint distribution with banks offering micro-lending has been a success .As of 2003, total number was about 500000 (http://www.bsnl.co.in/vptstatus.htm). New York Life insurance company has a license in India which obligates it to sell policies to the rural and disadvantaged; so it went for India's rich network of self-help and civic groups selling combos of phones and life insurance to institutions like fishermen's co-ops. The year 2007 is touted to be the year of ICT - rural connectivity, broadband, 3G, enterprise and entertainment bulge, mobile content, egovernance, increase in PC penetration, Information Security and telemedicine etc. It would also be the year, which will see telecom expanding into rural areas connecting possibly all the six-lakh villages. There is a Mission 2007 that promises to set up a Knowledge Centre in every village. That means some six lakh village knowledge centers with PCs, printers; web cameras, broadband connection, and power back up and so on. Broadband on fixed line and $3 G$ on wireless - these are set for convergence in 2007. That is also the year when central government expects its e-governance set up to being on the road to completion. And state governments would set up their data networks SWAN to reach all block headquarters.

Then there would be additions in the entertainment sector: digital television in more homes, better cable with some at least becoming interactive. On-line education, telemedicine, more content on mobile phones, enterprise services, IT applications in financial services, ecommerce.... 


\section{2) LARGE SCALE IMPORTED ADOPTION WITHOUT A TELECOMMUNICATIONS INFRASTRUCTURE AND TERMINALS INDUSTRY}

Despite the user and usage growth summarized in Section 0 , India today is a large net importer of almost all knowledge-intensive communications infrastructure and mobile terminals .Taking wireless networks alone (and except for physical buildings ,cables and power), it is estimated that the operator usage revenues after government taxes cover a $92 \%$ import quote for such systems . This is in a way quite an accomplishment only comparable amongst large economies to Indonesia, Pakistan, Nigeria and a few others. This shows that India is a significant case, although far from unique, of a large scale adoption without a native telecommunications infrastructure and terminals industry. Royalty and license fees receipts in 2002 represented 1/10 th of China's, high tech exports represent only $5 \%$ of manufactured exports (compared to China $23 \%$ ) while manufactured trade itself is only at $13 \%$ of GDP (2002) and total expenditure for R\&D was 0,78 \% of GDP in 2001 ( factor almost three less than China) (Worldbank) . Furthermore, since 1993-94 till 2005-06, according to data by Central Statistical Organisation (CSO), the average production of "telephone instruments" in India stands at 4.84 million (Indiastat). This shows that there are not enough domestic equipment manufacturers to cater to the needs. Having indigenous equipment manufacturers can help in reducing equipment cost as well as monthly rental cost, ensure faster delivery of goods, improve quality of services, and overall, increase the faith of the consumers in buying the goods.

In effect, India has lagged behind as a manufacturing center for communications systems and products (even falling behind other Asian countries), mainly because of infrastructure problems, and government regulations. And the few design or manufacturing centers are mostly foreign : Alcatel and partner ITI have opened a GSM infrastructure manufacturing plant in India , with CRM and test facilities (IEEE 2006) ; Texas Instruments and Freescale Semiconductor India Pvt (in Noida) develop a single phone chip , MXC Mobile extreme convergence architecture, and parts of Motorola Razr and Rokr cell phones ; NXP (exPhillips Semiconductor) India (in Bangalore) participate in a multimedia mobile processor ; Itiam Systems Pvt (in Bangalore) develop wireless ASICs ; HCL Technologies does design work for the IBM Power PC architecture family ,alongside IBM Bangalore ; SemIndia fab in Bangalore produces mobile phone chips outsourced by Broadcom ;Sony Ericsson will soon have manufacturing and some design in India . Although most potentially interested 
manufacturers back down early due to India's notorious distribution challenge , some like LG Electronics India have succeeded by going deeper into rural territories ,and serving at sales end users there which tend to pay a premium for quality and service, but only if they can afford the price .Some other companies want to use more the skills base to take advantage of the country's abundant supply of engineers .Companies that make the effort now to source and manufacture products in India may obtain first-mover advantages such as close relations with most suppliers, access to talent and government support :the fields of low cost mobile terminals, as well as of cabling and interconnect assemblies in telecoms infrastructure, are two important such areas ,in that the testing effort / design effort is high . Two high-profile multinationals, Intel and J. P. Morgan Chase, have announced their intention to move more skill-intensive operations to India. In back end telecoms, BSS or OSS, almost no such transfers have happened from abroad, largely due to legal and bureaucratic reasons

Similar lily, due to a slow reform in the domestic Indian financial system, there are far less Indian VC firms (today only about 30), but far more mergers and acquisitions or floats on the capital markets. Examples of Indian VC's active in telecommunications include: Sabeer Bhatia, Yogesh Patel, and Shiraz Kanga. The Indian VC's have mostly a flow of outbound investments, and give in this way evidence of their dependability and survivability to their main American or European clients. The conglomerates and operators do the same; e.g. not only does the Tata Group (14.2 Billion USD 2004/2005 turnover, or 2.6 \% of GDP) "hold 46 $\%$ stake in VSNL, India's incumbent international and national carrier. But Tata now also wants to invest in foreign operations like Tyco Global Networks (US) sub sea cable connection, Teleglobe International Holdings (Canada). Now VSNL International is targeting international wholesale and multinational enterprise markets (with or without call terminations in India), besides Teleglobe's large voice carrier volume .Indian high tech investments abroad of 3, 5 BUSD exceeded high tech India inbound investments in 2005. In the field of software and outsourcing services, in which India is a key player, Tata R\&D and design centre (Pune), Tata Consultancy services (TCS), Infosys, Motorola India Electronics Ltd (MIEL) (Bangalore) have become a prime supplier to foreign mobile infrastructure suppliers. Nevertheless, such Indian subcontractors receive increased competition from established global R\&D or IT service companies, and suffer from a shortage of workers fluent in european languages other than English .They are slow to raise beyond their roots and slow in building global organizations that can serve the telco infrastructure and operator segments with higher value added services (The McKinsey Quarterly, 2005) 
There is an almost never mentioned area of difficulties for the telecommunications industry in India, in that often patents there are granted to scientists at a conceptual level ,and they challenge specific design innovations by core suppliers .Under a British law and judicial system in India , and with bureaucratic hurdles, legal cases and disputes take far too long to resolve .The result is that essentially foreign players and domestic ones alike cannot rely on Indian IPR and that work for hire must be sole-ownership type to the funding party .

\section{3) UNSTABLE ADOPTION WITH LACK OF COHERENT PUBLIC POLICIES}

Ironically, India's telecommunications industry often has been cited as an example of how deregulation can unshackle growth. It has been one of the biggest corporate-success stories since the government opened the sector to private investment in the 1990s, in part, because it was one of the first sectors in India opened to foreign ownership. The government in 2006 lifted the foreign-shareholding cap for telecommunications companies to $74 \%$ from $49 \%$; New Delhi has yet to clarify the circumstances under which the foreigners are allowed to invest. But a recurrence of familiar old problems, regulatory roadblocks and foot-dragging by state-owned competitors (called "babus”), is threatening at times to cool expansion in India's wireless sector and is frustrating telecommunications investors. Phone-company executives want Indian regulators to make it easier to expand and to pressure the national state-run phone service BSNL to take steps needed to give millions of new private-network subscribers' access to the state-owned network. Consumers in some cities complain that the quality of their service is deteriorating, with a rising number of dropped calls and lousy reception. Meanwhile, wireless operators aren't earning in as much revenue as they should because unplanned growth, connectivity problems are jamming up networks and making it tougher to sell value-added services such as those that let users download games. All private operators say they need state-owned BSNL to keep up if growth rates and service quality are to be maintained and improved.

In 2005, Indian mobile operators have fallen woefully short of the government's goal for 2007. They added a mere $4 \mathrm{M}$ mobile subscribers during 1Q2005, and an additional $3 \mathrm{M}$ were added in the following two months. This takes the total mobile subscriber base in the country to $55 \mathrm{M}$, far away from where it should be if it were to add $152 \mathrm{M}$ before the end of 2007. If the regulatory regime is unable to immediately provide additional 2G spectrum to the country's operators and/or decides to levy a large license fee to award 3G spectrum, Pyramid Research believes that Indian 
operators will add a mere 54 M over 2005-2007, this will take the country's mobile subscriber base to $102 \mathrm{M}$ by 2007: almost 50 percent less than the government's stated objective.

One of the largest hurdles to overcome for operators is the issue of adequate spectrum. Currently, the average amount of spectrum awarded to an Indian GSM operator is between 4.4-10 MHz, while a CDMA operator receives between 2.5-5 MHz, amount considerably less than international benchmarks for both technologies. This has frequently led to, and will continue to result in inadequate planning and network building by operators. Operators need at least an additional 10-15 MHz swath of spectrum to ramp up capacity to meet the $200 \mathrm{~m}$ objective. Moreover, because the Finance Ministry recently suggested that 3G spectrum should be sold to operators for a license fee of up to US\$350 M, there is a doubt about the ability of Indian operators (even with foreign investment and backing) to finance their growth plans given the fact that their next allotment of spectrum might come at a hefty price tag. Regulators and politicians have been squabbling about which service providers deserve more spectrum and how they should pay for it. Some companies say spectrum should be auctioned off, while others say it should be allocated equally and paid for through revenue-sharing with the government. Still others want bandwidth to be allotted at a set price to only the largest operators that need it most.

The final obstacle to achieving $200 \mathrm{M}$ subscribers by 2007 is the fact that Indian operators face some of the highest telecom levies in the world, particularly among mobile carriers within developing markets. Service and general sales taxes, license fees, spectrum charges and universal fund obligations can account for anywhere from 15-24 percent of an operator's gross revenue in India. On the other hand, operators in countries such as China, Pakistan and Sri Lanka, are usually charged between 2-4 percent of their revenues in regulatory taxes and levies. Moreover, the 15-24 percent paid by Indian operators is on top of the Access Deficit Charge (ADC) - a fee of between 5-25 percent added on to per-minute tariffs to finance the development of fixed-line networks in the country. These exorbitant fees levied by the government continue to stunt the network build out plans of the country's operators, dampening the prospects of an industry expected to showcase high growth rates. 


\section{4) KNOWLEDGE SHARING AND PRODUCTIVITY ENHANCEMENT ADOPTION MODEL WITHOUT MANUFACTURING CONTRIBUTIONS}

In Section 3 it was already established that the communications service and product creation and manufacturing are playing only a very modest role towards the adoption of wireless services and products in India. The question however remains in terms of development model if this adoption was and is fueled by knowledge sharing and productivity enhancement alone.

In World Bank's Knowledge economy index ranking, India still ranks very low (about value 3 on scale of 10) (www.worldbank.org/kam) .Nevertheless, especially international organizations using the World Bank, "Knowledge Assessment Methodology," http://www.worldbank.org./KAM. have repeatedly pointed out at the Indian knowledge based economy's strength (Dahlman \& Utz, 2004). In so doing, however, the concept is used more broadly to cover how any economy harnesses and uses new and existing knowledge to improve the productivity of agriculture, industry, and services and increase overall welfare. In India, great potential exists for increasing productivity by shifting labour from low productivity and subsistence activities in agriculture, informal industry, and informal service activities to more productive modern sectors, as well as to new knowledge-based activities, and in so doing, to reduce poverty and touch every member of society. The NTP National Telecom Policy of 1999 For the first time also recognized the importance of telecom services for the social and economic development of the country (TRAI , 1999).India should continue to leverage its strengths to become a leader in knowledge creation and use. India has other intrinsic advantages, such as macroeconomic stability, a large domestic market, and a large and relatively low-cost and skilled workforce. It also has a critical mass of well-educated workers in engineering and science and, unlike China, abundant raw materials. India is still a relatively closed economy compared with other Asian economies, in which exports account for a much larger share of GDP (33 percent in China and 38 percent in the Republic of Korea, compared with only 15 percent in India in 2003).

There is a major difference between the types of network supported information content in rural and urban areas. In rural areas the need for communications is mostly related to emergency and social reasons, such as getting in touch with relatives at home and abroad or calling medical assistance .Economic activities rely still on personal contacts; however as mobile communication is well suited for this purpose, it has a large latent following for this use in Indian rural areas. Significant opportunities exist in information about agricultural 
input and output prices , basic banking and micro-loan opportunities, export regulation and law , weather forecasts , transport facilities including bus schedules, new agricultural techniques affecting production (World Bank, 2000) Creating new community services may happen fastest in : education and training, healthcare, environmental monitoring and emergency early warning ,entertainment (EU, 2001) .

In the urban areas, the knowledge economy is driven by businesses of all sizes and in all sectors, which all use wireless and satellite communications extensively, largely to reduce transaction costs and lowering the barriers of time and space. A recently rapidly growing dimension of the knowledge economy is the sudden explosion in R\&D ; whereas in most countries in the Organisation for Economic Co-operation and Development (OECD), the private sector finances 50-60 percent of $R \& D$, because it increasingly has the finance, knowledge, and personnel needed for technological innovation, in India, some 70 percent of $R \& D$ is performed by the central and state governments, an additional 27 percent by enterprises (both public and private sector industries), and less than 3 percent by universities and other higher education institutions.

Fierce price competition has resulted in Indian mobile telephony rates becoming one of the cheapest in the world. India's charges per minute are said to be the lowest in the world, as service providers offer deals that include a lifetime of unlimited incoming calls for a one-time fee of 1,000 rupees (\$21.75)."Everybody can afford it," said T. V. Ramachandran, director general of the Cellular Operators Association - "the teawallah, the dhobi and the sabsiwallah," conjuring up the traditional tea vendor, launderer and vegetable seller. Bharti Airtel's charges average national average of 3 UScents /min. Subscribers are responding to offerings like the Don't Stop Mobile plan of Tata Teleservices, which includes a handset and unlimited talk time for two years for just over US\$30. The mobile terminal maker Nokia recently introduced a mobile handset model costing the equivalent of US\$43.50, its lowest price globally for the handset, in partnership with Reliance Communication, one of India's largest telephone service providers. This has been a boon, mostly in urban areas but especially to people in India's 550,000 rural villages, which have had no access to communication through traditional means, such as fixed lines. But now, from fishermen at sea and brokers ashore in Kerala to farmers in Punjab-people in industry and farming are embracing wireless technology for economic activity, to do business, and to increase their profit margins.

India can also boast of better known remarkable and impressive global achievements in the IT sector; according to the National Association of Software and Services Companies (NASSCOM), the Indian IT market reached \$19.9 billion in 2003-04, accounting for about 
3.82 percent of India's GDP in 2003-04 and providing employment for almost a million people. India's IT services are moving up the value chain, and India is now undertaking new and innovative work, such as the management for clients of IT-related business processes. It is making an impact also in IT consulting, in which companies such as Wipro, Infosys, and Tata are managing IT networks for foreign companies and re-engineering business processes.

The real challenge is to promote the effective application and use of ICTs throughout the economy to raise productivity and growth, not just in a few pockets. Ensuring that the benefits of ICTs are shared by all requires an enabling environment for ICTs. Critical elements include increasing access to ICTs through widespread availability of telephones, increasingly including mobile phones, computers, and connectivity to the Internet; enhancing ICT literacy and skills among the population, more so in the rural areas; and developing ICT applications that can provide much-needed social, economic, and government services to citizens.

Indian operators are aiming to roll out 3G even before earlier generation services like GPRS take off. The country's telecom regulator is already beavering away on issues like the price of $3 G$ licenses, the allocation of spectrum and how much companies can charge for value-added services, and now it has allowed Bharat Sanchar Nigam Ltd., Mahanagar Telephone Nigam Ltd., Bharti Airtel and Hutchison Essar Ltd. to use 3G spectrum to test equipment in anticipation of a launch probably in 2007. Optimists say India can leapfrog slower-bandwidth tech with a speedy launch of 3G. But there are some questions whether India is really jumping ahead of the curve or blindly following in the footsteps of operators in more developed markets. The tale of high-end data, games, video downloads and Bollywood movies on your mobile, will only appeal to the "happy few". But 3G as a revenue booster in India is farfetched at this time .On the upside, freeing up the $3 \mathrm{G}$ band may alleviate a spectrum shortage, but it may hurt low end users.

It can be concluded that the knowledge sharing and productivity enhancement model is starting to impact selectively Indian adoption of wireless services and products as both an enabler and a result of needs.

\section{5) LATE FOREIGN CAPITAL INVESTMENTS INTO A LARGE EMERGING MARKET}


One established business model for large emerging markets is the one where foreign capital investments , when accepted, has fueled the adoption of communication services by taking either a longer term pay-back view or the view to establish a strong foothold early enough at lower costs . FCI is not, or has not been welcome for a long time (except with minority shares), in major markets like China, Russia , Indonesia, FCI has driven up the availability of wireless services and products in many places such as Central and South America, Africa , Vietnam, Pakistan and others .

The paradox with India has been that FCI in the communications sector with significant or majority stakes, has only be authorized so late that it could not boost the adoption of services and infrastructure deployment , and furthermore that it had to cope with low ROI due to the competitive rates set previously . Up until 2005 the direct foreign shareholding ceiling was 49 \% ,now raised to $74 \%$.Only in Internet services was 100 \% FCI authorized since 1999 (TRAI,1999) . As a matter of fact, some foreign early small stake investors had to leave due to too low ROI and bureaucratic hurdles. In 2003, Vodafone exited the Indian market and its $21 \%$ share in RPG Cellular , to re-enter late in 2005 with a $10 \%$ stake in Bharti Tele Ventures (about 1.5 BUSD) ,making it the largest foreign investment in India, valuing customers at 990 USD/subscriber .But for all the price it paid for this stake, Vodafone, was since 2005 till early 2007 only the second foreign investor in the company, next to Singapore Telecom , which has thrice the stake with 30,7 \% .The Mittal founder family has no intent of giving up control via their control over Bharti Telecom, itself largest shareholder in Bharti Tele Ventures . To add up to the FCI gyrations, recently Vodafone took over a large share in Hutchinson Essar in competition with a domestic conglomerate ,but the price/subscriber still outstrips by a very large factor the average ARPU so the only motivation can be business focussed value added services only .

Since Aug 1991 to Sep 2005, the telecommunications sector has attracted a cumulative inflow of Rs. 12,076 crore (US \$2,863 million), which amounts to $9.60 \%$ of the total FDI inflows attracted by India (Government of India,2005). The electrical equipment sector (including computer software and electronics) attracted Rs. 20, 898 Crore (US \$4,862 M), a share of $16.62 \%$ in the total FDI inflows (Government of India,2005). Between Aug 1991 to Aug 2004, looking at the Service/Item-wise actual inflow of FDI in the telecom sector, cellular mobile telephone services has attracted $28.87 \%$, holding companies, $47.13 \%$, basic telephony services, 3.83\%, manufacturing \& consultancy, 15.36\%, and Cable TV Network + Internet, 1.69\% (Indiastat) (Department of Telecommunications) . 


\section{COMPARISON OF ALTERNATIVE RELEVANT BUSINESS MODELS}

This paper has sofar reviewed ten business models for the adoption of wireless services and products in India , of which half are traditional one's while the last five are specific or unique relevant processes . The assessments are summarized in Table 3.

\begin{tabular}{|c|c|}
\hline Business model or effect & Relevance for India \\
\hline ABSORPTION BUSINESS MODEL & Largely invalid \\
\hline $\begin{array}{l}\text { PERCEIVED BENEFITS BUSINESS } \\
\text { MODEL }\end{array}$ & $\begin{array}{l}\text { Invalid until approx. } 2003 \text {; valid } \\
\text { thereafter }\end{array}$ \\
\hline CONSUMER ATTITUDES & Not valid \\
\hline $\begin{array}{l}\text { GLOBALISATION BUSINESS } \\
\text { MODEL }\end{array}$ & Largely invalid \\
\hline $\begin{array}{l}\text { BRAND MANAGEMENT BUSINESS } \\
\text { MODEL }\end{array}$ & Only valid for affluent groups in society \\
\hline TWO TIER MIGRATION MODEL & Valid and not sustainable \\
\hline $\begin{array}{l}\text { LARGE SCALE IMPORTED } \\
\text { ADOPTION WITHOUT A } \\
\text { TELECOMMUNICATIONS } \\
\text { INFRASTRUCTURE AND } \\
\text { TERMINALS INDUSTRY }\end{array}$ & Valid sofar and not sustainable \\
\hline $\begin{array}{l}\text { UNSTABLE ADOPTION WITH } \\
\text { LACK OF COHERENT PUBLIC } \\
\text { POLICIES }\end{array}$ & Valid sofar and not sustainable \\
\hline $\begin{array}{l}\text { KNOWLEDGE SHARING AND } \\
\text { PRODUCTIVITY ENHANCEMENT } \\
\text { ADOPTION MODEL WITHOUT } \\
\text { MANUFACTURING }\end{array}$ & Slowly emerging but risky \\
\hline
\end{tabular}




\begin{tabular}{|l|l|}
\hline CONTRIBUTIONS & \\
\hline LATE FOREIGN CAPITAL & Valid sofar despite recent events \\
INVESTMENTS INTO A LARGE & \\
EMERGING MARKET & \\
\hline
\end{tabular}

\section{Table 3: Summary table of adoption business models and of their relevance in} the Indian case

In view of this summary it appears that most traditional and stable adoption models from Section 2 fail to explain in a cohesive way the observed evolution In India across wireless user groups .On the contrary, most of the unique models or other structural processes identified in the subsequent Section 3 seem to give a better explanation of his evolution across wireless user groups .However most of these unique processes carry with them structural instabilities : imbalance across social groups, inconsistent public policies, weaknesses in the economic sectoral structure ,and sectoral balance of payment problems .

\section{CONCLUSION}

The combined result is an overall quite fragile adoption and deployment path with growing tensions such as coverage, quality of service and affordability disparities. Besides their usual instability, the unique structural processes share the characteristic of high dynamic fluctuation dependency which warrant some quantitative modelling via system dynamics; however the underlying phenomena are so fundamental or sporadic in time that the approximation quality would be doubtful.

The specific or unique characteristics prove that the adoption may only get sustainable if three conditions are jointly met:

- Stable transparent technology neutral regulations offering domestic and foreign investments alike a reasonable return even in a non growth scenario ;

- The exploitation of the potential of the rural areas with lower cost infrastructure and tariffing packages, with backbone infrastructure sharing and possibly some buildoperate-lease back arrangements for faster deployment 
- A reorientation of Indian industry towards tapping the growth opportunities ,once sustainable equilibrium margins can be reached, including turning into export opportunities instead of just being a large net importer

The lesson applies to the adoption of high technology services and products in India as elsewhere, that is that structural fragility and unseized opportunities deviating too much from a stable absorption process may jeopardize the perceived societal and business advantages.

\section{REFERENCES}

AIMA (All India Management Association), 2003. India’s New Opportunity, 2020: Report of the High-Level Strategic Group. Prepared with the Boston Consulting Group. Mumbai and New Delhi, India.

Baijal Pradip, 2004, "Building a foundation for nee technologies. Telecom Regulatory Authority of India”, ITU Digital Bridges Symposium, Busan, Korea

Bharat Rao and Mihir A. Parikh, 2003, "Wireless broadband drivers and their social implications” Technology in Society, Vol. 25, pp. 477-489.

Census of India, Government of India - Ministry of Home Affairs, Official Web-Site, http://www.censusindia.net/

Chang J., Fang X., Yen D., “China's telecommunication market for international investors: opportunities, challenges and strategies. Technology in Society, Vol. 27, pp. 105-121, 2005.

Chowdary, T. H., “Telecommunications in developing countries”, International Journal Information Technology and Management, Vol. 1, No. 4, pp. 325-344, 2002.

Cohe, W.M, Levinthal ,1990, Absorptive capacity : a new perspective on learning and innovation, Administrative science quarterly ,35, 128-152

Dahlman ,C., \& Utz, A., 2004, Macroeconomic outlook and steps towads a knowledge economy :India and the Knowledge Economy ;Leveraging Strengths and Opportunities , http://info.worldbank.org/etools/docs/library/145261/India_KE_Overview.pdf 
EU, 2001, "The information society and development: a review of the EC's experience in Asia, Latin America and th Mediterranean , DG External relations , Brussels

Floyd, D. And McManus, J.,2006, "The role and influence of Foreign Direct Investment on the development process: the case of the software industry in Romania, China, India and the Philippines", Global Business and Economics Review, Vol. 8, Nos.1/2 .

Fraunholz, B. and Unnithan, C.,2004, "Critical success factors in mobile communications: a comparative roadmap for Germany and India”, International Journal Mobile Communications, Vol. 2, No. 1, pp. 87-101

Government of India: Union Budget and Economic Survey, http://indiabudget.nic.in/

Government of India, 2005 : Union Budget and Economic Survey, Union Budget 2005-2006, available at: http://indiabudget.nic.in/, Feb $28^{\text {th }}, 2005$.

Government of India ,2006: Union Budget and Economic Survey, Union Budget 2006-2007, available at: http://indiabudget.nic.in/, Feb $28^{\text {th }}, 2006$.

Hong W. , 2005. "An Empirical Study on Telecommunications Development in the Rural Areas of China's Western Provinces”.

IEEE Spectrum , 2006, “Mobile ASIC and chip development”, March , pp 8-11

India, Planning Commission, 2001. India as Knowledge Superpower: Strategy for Transformation. New Delhi.

India, Planning Commission , 2002a. Tenth Five-Year Plan 2002-2007. New Delhi., http://planningcommission.nic.in /plans/planrel/fiveyr/welcome.html.

India, Planning Commission, 2002b, Report of the Steering Committee on Communication and Information for the Tenth Five-Year Plan (2002-2007). New Delhi.

http://planningcommission.nic.in/aboutus/committee/strgrp/stgp_candi.pdf.

India, Planning Commission, 2002c. India Vision 2020. New Delhi.

http://planningcommission.nic.in/reports/genrep/pl_vsn2020.pdf.

Indiastat: Revealing India Statistically, http://www.indiastat.com/ 
Internet Service Providers Association of India (ISPAI), http://www.ispai.in

Izumi A.,2002, A Comparative Study of Broadband in Asia: Deployment and Policy.”, Asia Network Research, pp. 1-25

Jain, R., 2006 "Interconnection regulation in India: Lessons for developing countries", Telecommunications Policy, Vol. 30, pp. 183-200.

Jhunjhunwala A., Narasimhan S., and Ramachandran A, 2003, "Enabling Rural Indian with Information and Communications Technology Initiatives”, International Telecommunication Union. Case Study, pp. 1-61

Kalam, A. P. J. Abdul, and Y. S. Rajan , 2002, India 2020: A Vision for the New Millennium. New Delhi: Penguin Books India.

Kanter,R.M.,1983, The change mastes , New York, NY: Simon and Schuster

Komandur S.,2004 "The Growth of Telecommunications-Dynamic Changes in India and Opportunities”, International Telecommunications Society 15th Biennial Conference, Berlin, Germany

Light Reading -Networking the Telecom Industry, India's Telecom Market Accelerates, http://www.lightreading.com/document.asp?doc id=86030

Maddison, A. , 2001, The World Economy: A Millennial Perspective. OECD, Paris.

Massoud, S. and Gupta, O. K., 2003, "Consumer perception and attitude towards mobile communications”, International Journal Mobile Communications, Vol. 1, No. 4, pp. 390-408

McKinsey Quarterly, October 2005

NASSCOM: National Association of Software and Service Companies, http://www.nasscom.in.

NASSCOM , 2004, (http://www.nasscom.org), NASSCOM’s IT Industry Factsheet 2004

(http://www.nasscom.org/download/IndianITIndustryFactsheet.doc)

Payal, M., 2004, “Indian Telecommunications Policy and Regulation: Impact on Investment and Market Structure”, http://regulateonline.org, Working Paper 
Press L., Foster W., Wolcott P., and McHenry W., 2003, “The Internet in India and China”, Information Technologies and International Development, Vol. 1(1), pp. 41-60

Rai,L.P. and and Lal,K., 2000, “Indicators of the information revolution”, Technology in Society, Vol. 22, pp. 221-235

Reynolds T., Kenny C., Liu J., and Qiang Z.,2004, “Networking for foreign direct investment: the telecommunications industry and its effect on investment”, Information Economics and Policy, Vol. 16, pp. $159-164$

Rogers,E.M., 1983 , Diffusion of innovation, New York, NY: Oxford University Press

Sangwan ,S. \& Pau,L-F ,2005, “Diffusion of mobile terminals in China”, European Management Journal , Vol 23 , no 6, december , 674-681

Stock, G.N, Greis, N.P, \& Fisher, W.A.,2001 Absoptive capacity and new product development , Journal of high technology management research , 12, 77-91

Telecommunications authority of India (TRAI), Study of rural telecommunications :http://www.trai.gov.in/27octconspap.pdf

Telecom Regulatory Authority of India (TRAI) ,1994, “National Telecom Policy 1994”, TRAI, http://www.trai.gov.in/ntp1994.htm.htm

Telecom Regulatory Authority of India (TRAI) ,1999, “National Telecom Policy 1999”, TRAI, http://www.trai.gov.in/npt1999.htm.

Telecom Regulatory Authority of India (TRAI), 2003 , “Consultation Paper on Accelerating Growth of Internet and Broadband Penetration”, TRAI Consultation Paper No. 6/2003, pp. 1-84

Telecom Regulatory Authority of India (TRAI) , 2004, “Growth of Telecom Services in Rural India TheWay Forward”, Consultation Paper No. 16/2004, TRAI Report, pp. 1-45

Telecom Regulatory Authority of India (TRAI) , 2005a , “Study Paper on Indicators for Telecom Growth” Study Paper No. 2/2005, pp. 1-23.

Telecom Regulatory Authority of India (TRAI), 2005b, “The Indian Telecom Services Performance Indicator Report for Q.E. Apr-Jun ‘05. 
Telecom Regulatory Authority of India (TRAI) ,2005c, “The Indian Telecom Service Performance Indicators Report for Q.E. July-Sept ‘05”, TRAI Report, pp. 1-115, December

Telecom Regulatory Authority of India (TRAI) ,2006a , "Telecom Subscribers Maintain Growth during March 2006”, Press Release No. 36/2006, April $10^{\text {th }}$

Telecom Regulatory Authority of India (TRAI) ,2006b , "The Indian Telecom Service Performance Indicators October - December 2005”, TRAI Report, pp. 1-79, April

UNDP, United Nations Development Program, Human Development Reports, http://hdr.undp.org/

Zahra, S.A, George,G., 2002 , "Absorptive capacity : a review, reconceptualization , and extension " , Academy of Management Review, 27, 185-203

Ziqi Liao , 2005, The adoption of mobile shot message services :implications for managing value added services in the telecommunication industry , Proc. 5 th Intl Conference on electronic business, Hong Kong, Dec 5-9 2005, 282-284

World Bank, 2000, "The networking revolution : opportunities and challenges for developing countries”, InfoDev working paper, Global information and communication technologies dept , Washington DC, June 


\section{Publications in the Report Series Research ${ }^{*}$ in Management}

\section{ERIM Research Program: "Business Processes, Logistics and Information Systems"}

2007

India: a Case of Fragile Wireless Service and Technology Adoption?

L-F Pau and J. Motiwalla

ERS-2007-011-LIS

A complete overview of the ERIM Report Series Research in Management: https://ep.eur.nl/handle/1765/1

ERIM Research Programs:

LIS Business Processes, Logistics and Information Systems

ORG Organizing for Performance

MKT Marketing

F\&A Finance and Accounting

STR Strategy and Entrepreneurship 